\title{
Stage of Knowledge of the Legislation Concerning Pine Forest Phytosanitary Protection
}

\author{
Ioan OROIAN ${ }^{1}$, Sînziana PAULIUC ${ }^{1}$, Ilie COVRIG ${ }^{2}$, Cristian IEDERAN ${ }^{1 *}$, Sorin POP ${ }^{1}$ \\ ${ }^{1}$ Faculty of Agriculture. University of Agricultural Science and Veterinary Medicine, Cluj - Napoca, \\ Romania \\ ${ }^{2}$ Faculty of Horticulture. University of Agricultural Science and Veterinary Medicine, Cluj - Napoca, \\ Romania \\ *Corresponding author: cristian.iederan@usamvcluj.ro
}

Bulletin USAMV series Agriculture 72(2)/2015

Print ISSN 1843-5246; Electronic ISSN 1843-5386

DOI 10.15835/buasvmcn-agr: 11745

\begin{abstract}
The issues concerning phytosanitary protection of forests generally speaking, and pine forests, particularly are in attention of scientists, in the field, worldwide. For this reason more concern is attribute to the regulations meant to rule the use of phytosanitary products used for maintaining the health of pine forests, and methodology of their administration. Our study aims to emphasize the degree of perception of aimed authorities, concerning the phytosanitary regulations connected to pine forest phytosanitary products. The methodology developed in this study concerns the means of sociological means, translated in bibliographical approach which involves the use of different documents, law texts, textbooks, and also the questionnaire instrument. As a result of our approach we highlight the most important issues meant to contribute to better protection of pine tree forests through an appropriate phytosanitary treatment, and also the most important issues concerning pine tree forests maintaining focused by the actors involved in their maintaining. The phytosanitary regulations play a decisive role in maintaining the health of forests, generally speaking and of pine tree forests, in particularly. They supply a general frame for appropriate treatments for suitable forest development.
\end{abstract}

Keywords: law, questionnaire, regulations, methodology

\section{INTRODUCTION}

The issues concerning phytosanitary protection of forests generally speaking, and pine forests, particularly are in attention of scientists, in the field, worldwide. For this reason more concern is attribute to the authorities' perception concerning regulations meant to rule the use of phytosanitary products used for maintaining the health of pine forests, and methodology of their administration (Oroian and Petrescu - Mag, 2010).

In particular case of Romania, we have to mention that a different approach of this complex issue is reported since 1 January 2007 , because this date marks the Romanian accession to European Union, as a full member. Since this milestone, our country had a great responsibility in terms of meeting the communitarian acquis (Porumbăcean, 2009). In the present context, legislative issues related to plant protection, generally speaking, and pine forest protection, in particular, is of paramount importance for our country (Oroian and Petrescu - Mag, 2010; Toderoiu, 2004).

The transposition of $\mathrm{EU}$ directives into national regulations, in addition to coercive character imposed by Romania membership to the European Union, brings benefits related to improving plant protection performances. In this way, as a result of adopting EU legislation, it helps to better fight against the emergence and spread of native pests and pathogens as well as against phytosanitary quarantine organisms (Oroian and Petrescu - Mag, 2010; Porumbăcean, 
2009). The EU legislative package needed to be transposed in national legislation also contributes to improving of use of pesticides (in terms of protection for living organisms) in the meantime with enhancing environmental protection actions. In this regard, we note that ourdays the EU regulations concerning phytosanitary protection are transposed in Romanian laws, ordinances and Romanian Government Decisions.

All these documents represent the result of the transposition, in Romania, of legislation adopted at European Union. This legislation is also implemented in all $28 \mathrm{EU}$ member countries, and provide a solid system for controlling the plant protection and environmental protection policies in concerned countries (Oroian and Petrescu Mag, 2010).

In this paper we aim to emphasize the degree of perception of aimed authorities, concerning the phytosanitary regulations connected to pine forest phytosanitary products.

\section{MATERIALS AND METHODS}

In order to collect data concerning the perception of competent factors, involved in the application of laws adopted in European Union regarding pine forest health transposed into Romanian legislation, and also the degree ok knowledge of the transposition degree in preset, a sociological methodology was adopted (Grawitz,
2000). In this respect, in our study a questionnaire was drafted.

The questionnaire is focused on respondents' familiarity with the most important components of pine forest phytosanitary legislation, but also on respondents' knowledge concerning the specific phytosanitary products.

In order to obtain a good reflection of reality, the questionnaire was distributed randomly to 150 subjects from County Phytosanitary Offices, who are specialized in phytosanitary protection in overall, and some of them in pine forest phytosanitary protection. The randomly selected subjects have different experience in the field, from one year, up to more than 30 years of work.

The collected data were processed and results were graphically expressed, as share of questioned subjects.

\section{RESULTS AND DISCUSSION}

The results of our study demonstrate the particularities of the degree of knowledge recorded in authorities responsible with phytosanitary protection, generally speaking, and with pine forest in particular.

The representatives of the authorities responsible with forest phytosanitary protection, with preoccupation concerning pine forests maintenance, have satisfactory knowledge of the phytosanitary regulations concerning the control

\section{QUESTIONNAIRE CONCERNING STAGE OF KNOWLEDGE OF THE LEGISLATION CONCERNING PINE FOREST PHYTOSANITARY PROTECTION}

\begin{tabular}{c} 
1. What is the level of your knowledge concerning the phytosanitary regulations of pine forest protection \\
products ? \\
$\square$ Very good \\
\hline Good \\
\hline S. What is the level of your knowledge concerning the EU phytosanitary legislation referring to the control \\
of pine forest protection products ?
\end{tabular}

What is the level of your knowledge concerning the degree of transposition of the EU phytosanitary

3. legislation into Romanian legislation regarding phytosanitary regulations referring to the control of pine forest protection products?

\begin{tabular}{|c|c|c|c|c|}
\hline & $\square$ Very good & $\square$ Good & $\square$ Satisfactory & $\square$ Do not know \\
\hline \multirow[t]{2}{*}{4.} & $\begin{array}{c}\text { What is the level of your kn } \\
\text { the introducing in }\end{array}$ & $\begin{array}{l}\text { ge concern } \\
\text { t of phytos }\end{array}$ & $\begin{array}{l}\text { age of implement } \\
\text { oducts of pine for }\end{array}$ & $\begin{array}{l}\text { of the legislation referring to } \\
\text { otection products? }\end{array}$ \\
\hline & $\square$ Very good & $\square$ Good & $\square$ Satisfactory & $\square$ Do not know \\
\hline
\end{tabular}


of pine forest protection products, expressed as share among respondents it is in percent of $52.20 \%$, while $30.80 \%$ have good knowledge, $7.50 \%$, very good knowledge, and $9.50 \%$ have no information in the field (Fig. 1).

Concerning the representatives of the authorities responsible with forest phytosanitary protection, with preoccupation concerning pine forests maintenance, have satisfactory knowledge of the phytosanitary regulations concerning the control of pine forest protection products, expressed as share among respondents it is in percent of $70 \%$, while $12.30 \%$ have good knowledge, and $17.70 \%$, very good knowledge (Fig. 2).

The degree of transposition of the EU phytosanitary legislation into Romanian legislation concerning phytosanitary regulations concerning the control of pine forest protection products is very well good documented by the representatives of the authorities responsible with forest phytosanitary protection, with preoccupation concerning pine forests maintenance, in share of $9.30 \%$, while $60 \%$ of respondents have satisfactory knowledge and $30.70 \%$ of them have good information in the field (Fig. 3). Concerning this issue we notice that all study subjects have knowledge in this field.

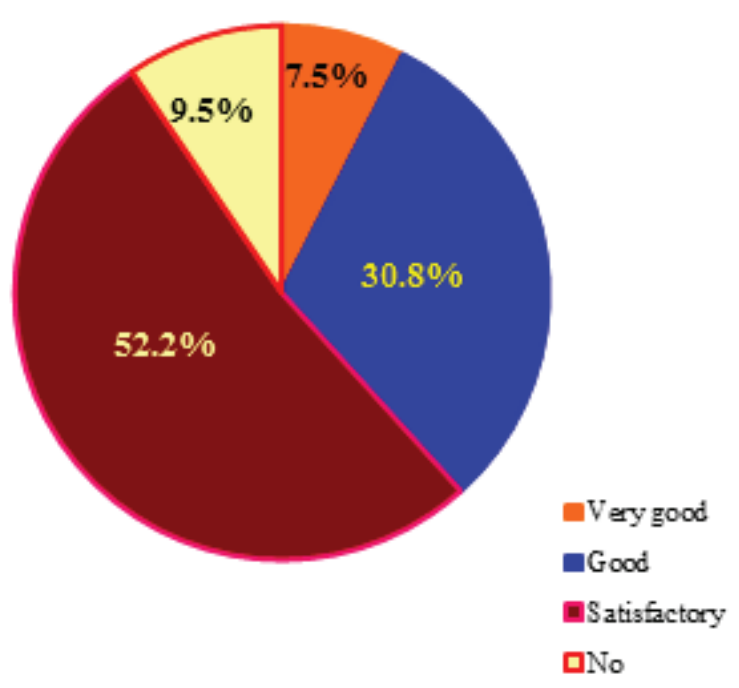

Fig. 1. The knowledge of the phytosanitary regulations concerning the control of pine forest protection products, expressed as share among respondents
In what concerns the stage of implementation of the legislation concerning the introducing in market of phytosanitary products of pine forest protection products, the representatives of the authorities responsible with forest phytosanitary protection, with preoccupation concerning pine forests maintenance, have satisfactory knowledge of the regulations phytosanitary regulations concerning the control of pine forest protection products, expressed as share among respondents it is in percent of $45.80 \%$ (Fig. 4).

A share of $8.40 \%$ of the respondents have good knowledge, $30.80 \%$, very good knowledge, while $8.40 \%$ have no information in this area (Fig. 4).

\section{CONCLUSIONS}

Very good knowledge of regulations is reported concerning EU phytosanitary legislation concerning phytosanitary regulations concerning the control of pine forest protection products, and degree of transposition of the EU phytosanitary legislation into Romanian legislation concerning phytosanitary regulations concerning the control of pine forest protection products.

Concerning knowledge of the phytosanitary regulations and stage of implementation of the legislation regarding the control of pine forest

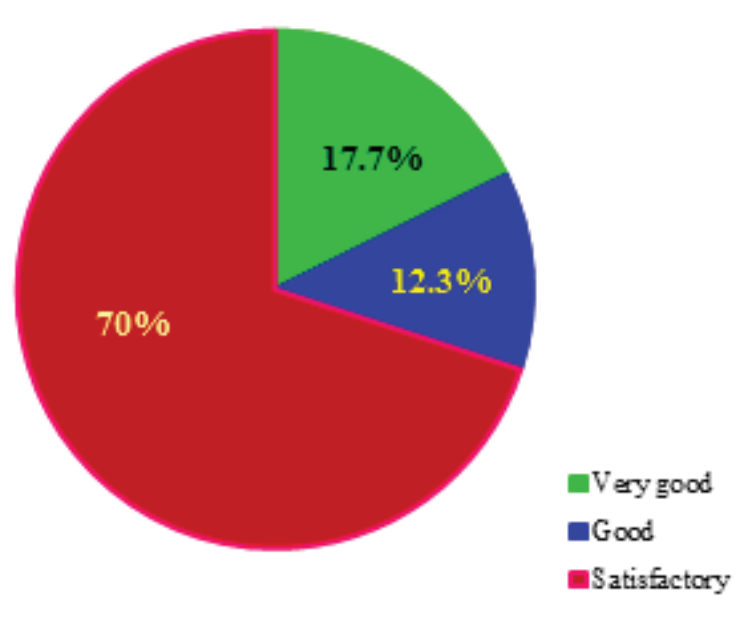

Fig. 2. The knowledge of the EU phytosanitary legislation concerning phytosanitary regulations referring to the control of pine forest protection products, expressed as share among respondents 


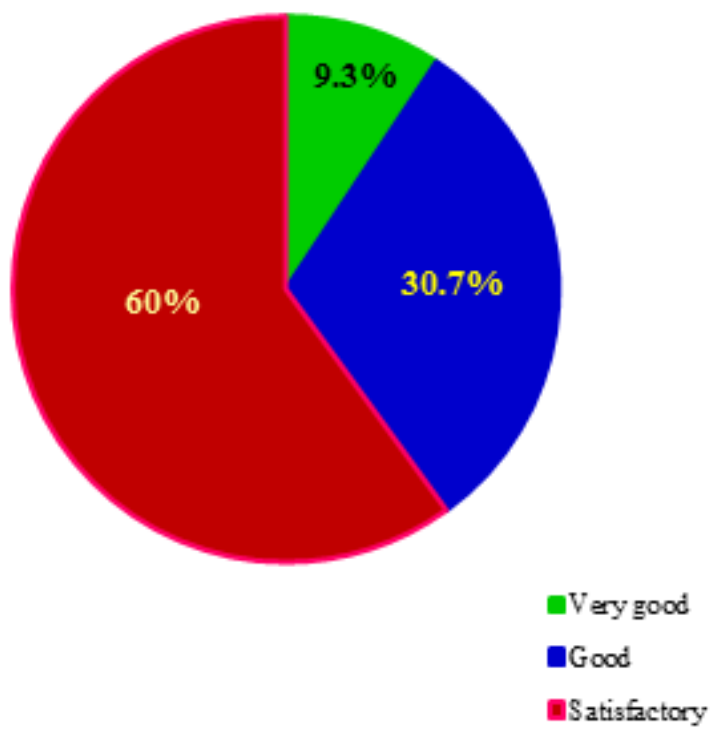

Fig. 3. The knowledge of the degree of transposition of the EU phytosanitary legislation into Romanian legislation concerning phytosanitary regulations referring to the control of pine forest protection products, expressed as share among respondents

protection products, satisfactory knowledge is noticed, even low percent of respondents, $9.50 \%$ in first case, and $8.50 \%$ in second, have no knowledge in the approached field.

The implementation of the questionnaire concerning the particularities of the degree of knowledge recorded in authorities responsible with phytosanitary protection, generally speaking, and with pine forest in particular, demonstrates a satisfactory to good competences of approached legislation, in European Community regulations context.

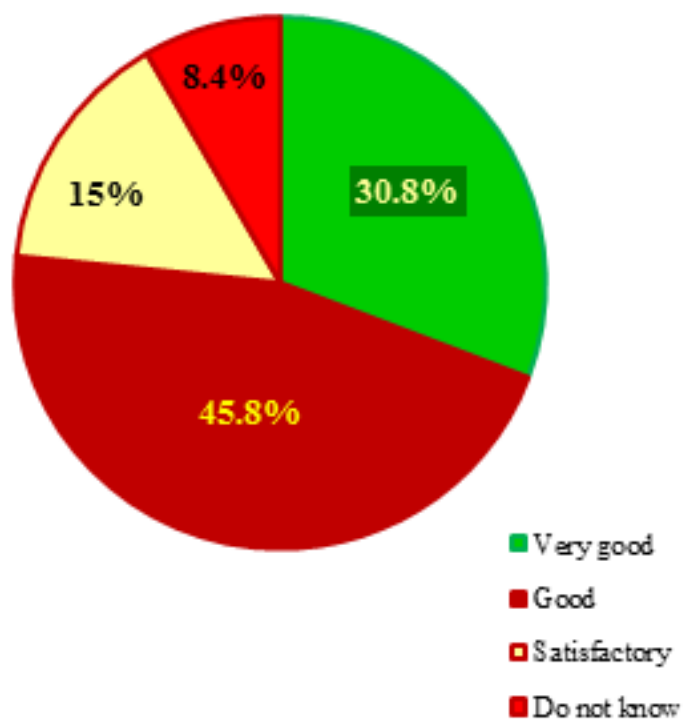

Fig. 4. The stage of implementation of the legislation concerning the introducing in market

of phytosanitary products of pine forest protection products, in respondents' vision - \%

\section{REFERENCES}

1. Grawitz M (2000). Méthodes des sciences sociales, Dalloz Publishig House, Paris, France [In French].

2. Oroian I, Petrescu -Mag M (2010). Envirionmental law and legislation, Bioflux Publishing House Cluj-Napoca, Romania [In Romanian].

3. Porumbăcean C (2009). The European Union policies and institutions, Vasile Goldiș Publishing House, University Press, Arad, Romania [In Romanian].

4. Toderoiu F (2004). The agricultural files of EU accession - from uncovered optimism to real cover, The Publishing House of Academy of Economic Studies Bucharest, Romania [In Romanian]. 